\title{
Determinants of Long-Term Contraceptive Method Use in Madiun, East Java: Application of Social Cognitive Theory
}

\author{
Kartika'), Uki Retno Budihastuti²), Eti Poncorini Pamungkasari3) \\ ${ }^{1)}$ Masters Program in Public Health, Universitas Sebelas Maret \\ 2)Department of Obstetric and Gynecology, Dr. Moewardi Hospital, Surakarta \\ 3)Department of Public Health, Faculty of Medicine, Universitas Sebelas Maret
}

\begin{abstract}
Background: Indonesia ranks 5 in the world by the number of population. It has Total Fertility Rate of 2.6, which is higher than average rate in South East Asia. In order to control population growth the Indonesian Government has attempted to increase the utilization of the long-term contraceptive method. This study aimed to determine determinants of long-term contraceptive method use in Madiun, East Java with the application of social cognitive theory.

Subjects and Method: This was an analytic observational study with case control design. Study subjects consisted of 50 women of reproductive age who had used long term contraceptive method and 100 similar women who had not. The dependent variable was use of long-term contraceptive method. The independent variables were education level, knowledge, attitude, culture, information access, and decision maker. The data were collected using a set of questionnaire and analyzed by path analysis in STATA.

Results: Use of long-term contraceptive method were positively affected by high education level $(b=1.31 ; 95 \% \mathrm{CI}=0.13$ to $2.50 ; \mathrm{p}=0.029)$, positive attitude $(\mathrm{b}=2.45 ; 95 \% \mathrm{CI}=1.47$ to 3.43$)$; $\mathrm{p}<0.001$ ), and joint decision making $(\mathrm{b}=2.02 ; 95 \% \mathrm{CI}=0.91$ to $3.13 ; \mathrm{p}<0.001)$. Joint decision making was affected by positive attitude $(b=1.27 ; 95 \% \mathrm{CI}=0.58$ to $1.96 ; \mathrm{p}<0.001)$. Positive attitude was affected by good knowledge $(b=0.75 ; 95 \% \mathrm{CI}=0.09$ to $1.49 ; \mathrm{p}=0.047)$ and positive culture $(\mathrm{b}=$ $1.44 ; 95 \% \mathrm{CI}=0.70$ to $2.17 ; \mathrm{p}<0.001)$. Good knowledge was affected by good information access $(\mathrm{b}=0.96 ; 95 \% \mathrm{CI}=0.20$ to $1.63 ; \mathrm{p}=0.005)$.
\end{abstract}

Conclusion: Use of long-term contraceptive method is positively affected by high education level, positive attitude, and decision making.

Keywords: Use of long term contraceptive method, women of childbearing age, family planning

\section{Correspondence:}

Kartika. Masters Program in Public Health, Universitas Sebelas Maret, Jl. Ir. Sutami 36 A, Surakarta 57126, Central Java. Email: tsurayya.kartika@gmail.com. Mobile: +6281803339900.

\section{BACKGROUND}

The current global problems are caused by the growing population of the world. Birth rates in some countries have increased considerably, affecting the socioeconomic conditions of a country in general and the health conditions of women and children in particular (Sahilemichael, et al 2015). Indonesia is one of the most populous countries in the world. Indonesia population is ranking $5^{\text {th }}$ in the world that its growth rate is still relatively high. This is seen from the total fertility rate of 2.6 which means there is above the average total fertility rate of ASEAN Countries is 2.4 (Ministry of Health RI, 2014).

The problem in the management of family planning program is that there is still high rate of family planning Unmet need in Indonesia. Nationally, the number of fertile couples who want to delay pregnancy or do not want additional children, but do not do family planning, has 
increased by $11.4 \%$ in 2012 to $14.87 \%$ by 2014 (BKKBN, 2015).

Based on data from Madiun City Health Office, the coverage of active participants for Long Term Contraception Method in the year 2015 amounted to (38.5\%). It is decreased compared to 2014 (39.44\%). The decreasing use of long term contraceptive method is due to the increase of interest in using contraceptive tools non long term contraceptive method for fertile couples. Therefore that counseling in the use of long-term contraceptive tools should be increased to reduce the number of failures that occurred in Madiun City (Madiun City Health Office, 2015).

One of the population and national family planning division targets for reducing population growth through the family planning program is to increase the use of long-term contraceptive methods by $10.6 \%$ in 2012 to $23.5 \%$ by 2019 (Ministry of Development Planning National, 2014). Long-term contraceptive methods is a method of contraception that has a low failure rate and is considered efficient because it can be used for long periods of time, safely and effectively in preventing pregnancy (Teferra, et al, 2015).

Factors that influence the family planning acceptors in choosing family planning tools are: motivation factors, including the accessibility of family planning services, the support of the husband, the need factor of contraceptive security, and socioeconomics include the trained health worker and the cost affordable (Manurung, 2013). Factors that affect a person to be able to change his health behavior is through the prevailing social norms in the surrounding life. The theory approach that studies it is the social learning theory (Social Cognitive Theory) proposed by Bandura in 1967. This theory is also called the social awareness theory that focuses on three determinants that affect human behavior. This factor is based on interrelated three-way reciprocal models: personal cognitive factors, environmental factors, and behavioral factors. This study focuses on analyzing the determinants in the use of Long Term Contraception Methods in the working area of Banjarejo Community Health Centre in Madiun.

\section{SUBJECTS AND METHOD}

This was an analytical observational study with a case control design. The study was conducted at Banjarejo Community Health Centre, Madiun, East Java.

The population in this study was case population that was all women of reproductive age (age 15-49 years) using long term contraceptive method in Banjarejo Community Health Centre, Madiun. Samples were selected by fixed disease sampling.

The dependent variable was the use of long term contraceptive method. The independent variables were education level, knowledge, attitude, information access, culture, and decision making.

The operational definition of education level is the last formal education of childbearing age women that obtained a diploma. Access to information is the acquisition of information in the form of knowledge about contraception delivered through counseling and media activities. Culture is a belief that becomes a reference in the long-term use of contraception. Knowledge is the right knowledge of longterm contraception. Attitude is a positive or negative assessment of long-term use of contraception. Decision-making is the effort to make choices independently or together in the use of contraception.

The data were collected by questionnaire. Data were analyzed using path 
analysis with Stata 13. Based on the results of total-item correlation reliability test, it was found that on the information access, knowledge, culture, attitude, and decision making the value of $r$ count $\geq 0.20$, and
Cronbach's Alpha $\geq 0.70$, so that all the questions were declared reliable. Reliability test results of the questionnaire could be seen in Table 1.

Table 1. Reliability Test Results

\begin{tabular}{lcc}
\multicolumn{1}{c}{ Variable } & Item Total Correlation (r) & Cronbach Alpha \\
\hline Information Access & $>0.22$ & 0.74 \\
Knowledge & $>0.24$ & 0.74 \\
Culture & $>0.27$ & 0.71 \\
Attitude & $>0.21$ & 0.71 \\
Decision Making & $>0.29$ & 0.71 \\
\hline
\end{tabular}

\section{RESULTS}

The characteristic dimension of 150 subjects was viewed from the education level of study subjects <Senior high school as many as 42 subjects with a percentage of 28\% and $\geq$ High School as many as 108 subjects with a percentage of $72 \%$. The characteristic dimension of 150 subjects was viewed from the work, there were working WCAB as many as 43 subjects with a percentage of $28.6 \%$ and do not working WCAB as many as 107 subjects with a percentage of $71.3 \%$. Characteristics of subjects in this study can be seen in Table 2.

Table 2. Characteristics of Study Subjects

\begin{tabular}{|c|c|c|}
\hline \multirow{2}{*}{\multicolumn{3}{|c|}{$\begin{array}{c}\text { Characteristics } \\
\text { Education Level of WCBA }\end{array}$}} \\
\hline & & \\
\hline$<$ High School & 42 & 28 \\
\hline$\geq$ High School & 108 & 72 \\
\hline $\begin{array}{l}\text { Work } \\
\text { Working }\end{array}$ & 43 & 28.6 \\
\hline Do not working & 107 & 71.3 \\
\hline
\end{tabular}

Descriptive statistics of each variable included minimum value, maximum value, mean value and standard deviation. Table 3 was for measuring variables with continuous scales, both dependent and independent variables. Mean represents the

Table 3. Description of the Variables

\begin{tabular}{lccccc}
\hline \multicolumn{1}{c}{ Variables } & $\mathbf{n}$ & Min. & Max. & Mean & SD \\
\hline Information access & 150 & 1 & 12 & 8.406 & 2.288 \\
Culture & 150 & 1 & 6 & 4.693 & 0.835 \\
Knowledge & 150 & 10 & 17 & 14.52 & 1.39 \\
Attitude & 150 & 1 & 10 & 6.03 & 3.02 \\
Decision Making & 150 & 1 & 10 & 7.62 & 1.94 \\
\hline
\end{tabular}

The result of bivariate analysis showed that there was a correlation between education level with the use of mean value, whereas the standard deviation (SD) describes how far the data varies.The small SD value is an indication that the data is representative. The results of descriptive statistics for continuous data could be seen in Table 3. long term contraceptive method family planning and it was statistically significant. Women of reproductive age with higher 
Journal of Health Promotion and Behavior (2017), 2(4): 313-322

https://doi.org/10.26911/thejhpb.2016.02.04.03

education level ( $\geq$ High School) were likely contraceptive method family planning (OR to be 5.28 times higher to use long term $=5.28 ; 95 \% \mathrm{CI}=1.92$ to $14.5 ; \mathrm{p}=0.001)$.

Table 4. Bivariate analysis of education level, information access, culture, knowledge, attitude, decision making, long term contraceptive method use

\begin{tabular}{|c|c|c|c|c|c|c|c|c|c|}
\hline \multirow{3}{*}{ Variable } & \multirow{3}{*}{ Category } & \multicolumn{4}{|c|}{$\begin{array}{c}\text { Long term } \\
\text { contraceptive method }\end{array}$} & \multirow{3}{*}{ OR } & \multirow{2}{*}{\multicolumn{2}{|c|}{ CI 95\% }} & \multirow{3}{*}{$\mathbf{p}$} \\
\hline & & \multicolumn{2}{|c|}{ Yes } & \multicolumn{2}{|c|}{ No } & & & & \\
\hline & & $\mathbf{n}$ & $\%$ & $\mathbf{n}$ & $\%$ & & $\begin{array}{l}\text { Lower } \\
\text { limit }\end{array}$ & $\begin{array}{l}\text { Upper } \\
\text { limit }\end{array}$ & \\
\hline Education & $\begin{array}{l}<\text { Senior high } \\
\text { school } \\
\geq \text { Senior high } \\
\text { school }\end{array}$ & $\begin{array}{c}5 \\
45\end{array}$ & $\begin{array}{l}11.9 \\
41.7\end{array}$ & $\begin{array}{l}37 \\
63\end{array}$ & $\begin{array}{l}88.1 \\
58.3\end{array}$ & 5.28 & 1.92 & 14.5 & $\begin{array}{c}0.00 \\
1\end{array}$ \\
\hline $\begin{array}{l}\text { Informatio } \\
\text { n Access }\end{array}$ & $\begin{array}{l}\text { Poor } \\
\text { Good }\end{array}$ & $\begin{array}{c}9 \\
41\end{array}$ & $\begin{array}{l}11.3 \\
58.6\end{array}$ & $\begin{array}{l}71 \\
29\end{array}$ & $\begin{array}{l}88.8 \\
41.4\end{array}$ & 11.15 & 4.81 & 25.85 & $\begin{array}{c}<0.0 \\
01\end{array}$ \\
\hline Culture & $\begin{array}{l}\text { Do not support } \\
\text { Support }\end{array}$ & $\begin{array}{c}4 \\
46\end{array}$ & $\begin{array}{c}5.8 \\
56.8\end{array}$ & $\begin{array}{l}65 \\
35\end{array}$ & $\begin{array}{l}94.2 \\
43.2\end{array}$ & 21.36 & 7.1 & 64.24 & $\begin{array}{c}<0.0 \\
01\end{array}$ \\
\hline Knowledge & $\begin{array}{l}\text { Low } \\
\text { High }\end{array}$ & $\begin{array}{l}15 \\
35\end{array}$ & $\begin{array}{l}16.9 \\
57.4\end{array}$ & $\begin{array}{l}74 \\
26\end{array}$ & $\begin{array}{l}83.1 \\
42.6\end{array}$ & 6.64 & 3.13 & 14.08 & $\begin{array}{c}<0.0 \\
01\end{array}$ \\
\hline Attitude & $\begin{array}{l}\text { Negative } \\
\text { Positive }\end{array}$ & $\begin{array}{c}7 \\
43\end{array}$ & $\begin{array}{c}9.1 \\
58.9\end{array}$ & $\begin{array}{l}70 \\
30\end{array}$ & $\begin{array}{l}90.9 \\
41.1\end{array}$ & 14.33 & $5 \cdot 79$ & 35.47 & $\begin{array}{c}<0.0 \\
01\end{array}$ \\
\hline $\begin{array}{l}\text { Decision } \\
\text { Making }\end{array}$ & $\begin{array}{l}\text { Independently } \\
\text { Joint decision }\end{array}$ & $\begin{array}{c}5 \\
45\end{array}$ & $\begin{array}{c}8.1 \\
51.1\end{array}$ & $\begin{array}{l}57 \\
43\end{array}$ & $\begin{array}{l}91.9 \\
48.9\end{array}$ & 11.93 & 4.36 & 32.59 & $\begin{array}{c}<0.0 \\
01\end{array}$ \\
\hline
\end{tabular}

There was a correlation between access to information with the use of long term contraceptive method family planning and it was statistically significant. Women of childbearing age who had access to good information were likely to be $\mathbf{1 1 . 1 5}$ times higher to use long term contraceptive method D family planning (OR = 11.15; 95\% $\mathrm{CI}=4.81$ to $25.85 ; \mathrm{p}<0.001)$.

There was a correlation between culture with the use of long term contraceptive method family planning and it was statistically significant. Women of childbearing age who had a supportive culture were likely to be 21.36 times higher to use long term contraceptive method family planning $(\mathrm{OR}=21.36 ; 95 \% \mathrm{CI}=7.1$ to 64.24 ; $\mathrm{p}<0.001)$.

Women of childbearing age who had higher level of knowledge were likely to be 6.64 times higher to use long term contraceptive method family planning. The result of the analysis showed that there was a correlation between knowledge with the use of long term contraceptive method family planning and it was statistically significant $(\mathrm{OR}=6.64 ; 95 \% \mathrm{CI}=3.13$ to 14.08; $\mathrm{p}<0.001$ ).

Women of childbearing age who had positive attitude were likely to be $\mathbf{1 4 . 3 3}$ times higher to use long term contraceptive method family planning. The result of the analysis showed that there was a correlation between attitude with the use of long term contraceptive method family planning and it was statistically significant $(\mathrm{OR}=14.33$; $\mathrm{CI} 95 \%=5.79$ hingga 35.47 ; $\mathrm{p}<0.001)$.

Women of childbearing age with joint decision making were likely to be 11.93 times higher to use long term contraceptive method family planning. The result of the analysis showed that there was a correlation between decision making with early marriage and it was statistically significant $(\mathrm{OR}=11.93$; $\mathrm{CI} 95 \%=4.36$ hingga 32.59; $\mathrm{p}<0.001)$. 
The results of the path analysis in Table 5 showed that there was a direct influence of the high level of education on the use of long term contraceptive method family planning, and it was statistically significant. Women of Childbearing Age (WCBA) who were highly educated were more likely to increase the use of long term contraceptive method $(\mathrm{b}=1.31 ; 95 \% \mathrm{CI}=$ 0.13 to $2.50 ; \mathrm{p}=0.029$ ).

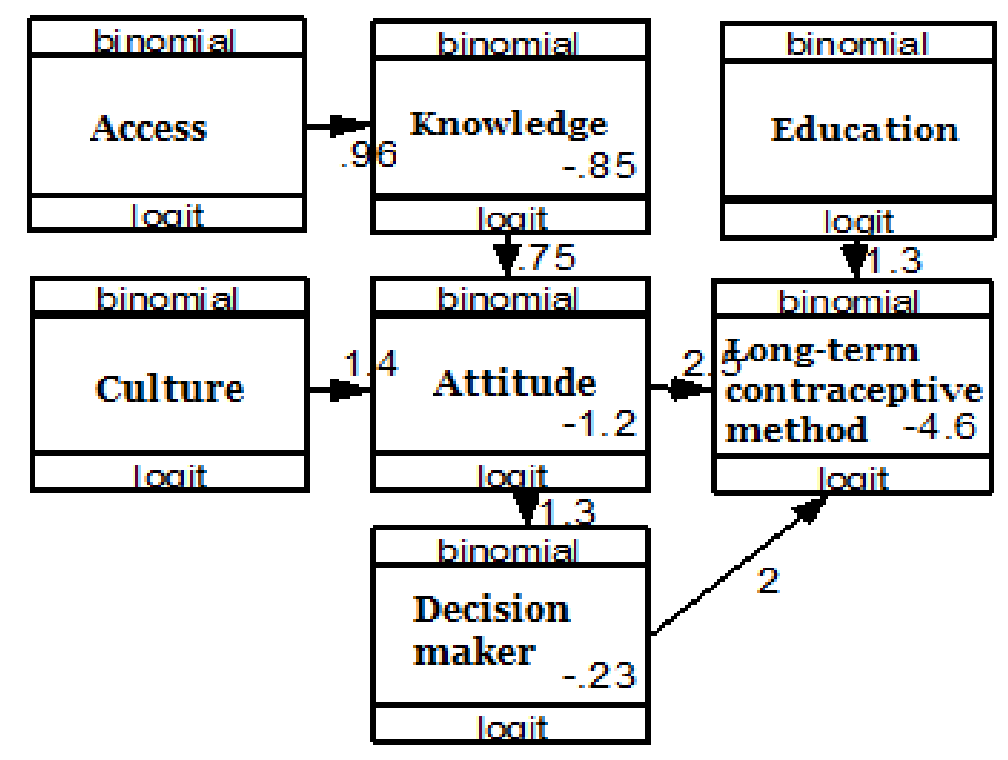

Figure 1. Structural model of path analysis with estimation

Table 5. The Result of Path Analysis

\begin{tabular}{|c|c|c|c|c|c|c|}
\hline \multirow[b]{2}{*}{$\begin{array}{l}\text { Independent } \\
\text { Variable }\end{array}$} & & \multirow[b]{2}{*}{ Dependent Variable } & \multirow[b]{2}{*}{$\mathbf{b}$} & \multicolumn{2}{|c|}{ CI 95\% } & \multirow[b]{2}{*}{$\mathbf{p}$} \\
\hline & & & & $\begin{array}{c}\text { Lower } \\
\text { Limit }\end{array}$ & $\begin{array}{c}\text { Upper } \\
\text { Limit }\end{array}$ & \\
\hline $\begin{array}{l}\text { Direct Effect } \\
\text { Long term } \\
\text { contraceptive use }\end{array}$ & $\leftarrow$ & $\begin{array}{l}\text { Education } \geq \text { Senior high } \\
\text { School }\end{array}$ & 1.31 & 0.13 & 2.50 & 0.029 \\
\hline & $\leftarrow$ & Positive Attitude & 2.45 & 1.47 & 3.43 & $<0.001$ \\
\hline Indirect Effect & $\leftarrow$ & Joint Decision Making & 2.02 & 0.91 & 3.13 & $<0.001$ \\
\hline Positive Attitude & $\leftarrow$ & High Knowledge & 0.75 & 0.09 & 1.49 & 0.047 \\
\hline Joint Decision Making & $\leftarrow$ & Positive Attitude & 1.27 & 0.58 & 1.96 & $<0.001$ \\
\hline Higher Knowledge & $\leftarrow$ & $\begin{array}{l}\text { Good Information } \\
\text { Access }\end{array}$ & 0.96 & 0.29 & 1.63 & 0.005 \\
\hline Positive Attitude & $\leftarrow$ & Supportive Culture & 1.44 & 0.70 & 2.17 & $<0.001$ \\
\hline
\end{tabular}

Women of Childbearing Age with a positive attitude were more likely to increase the use of long term contraceptive method (b $=2.45 ; 95 \% \mathrm{CI}=1.47$ to $3.43 ; \mathrm{p}$ $<0.001)$.

Women of Childbearing Age with joint decision making on family planning were more likely to increase the use of long term contraceptive method $(b=2.02 ; 95 \%$ $\mathrm{CI}=0.91$ to $3.13 ; \mathrm{p}<0.001)$.
Women of Childbearing Age with higher level of knowledge were more likely to increase the positive attitude $(b=0.75$; CI 95\% $=0.09$ hingga 1.49; $\mathrm{p}=0.047$ ).

Women of Childbearing Age with positive attitude were more likely to increase joint decision making $(\mathrm{b}=1.27$; $95 \% \mathrm{CI}=0.58$ to $1.96 ; \mathrm{p}<0.001$ )

Women of Childbearing Age with good information access were more likely to 
Journal of Health Promotion and Behavior (2017), 2(4): 313-322

https://doi.org/10.26911/thejhpb.2016.02.04.03

increase better knowledge $(\mathrm{b}=0.96 ; \mathrm{CI}$ $95 \%=0.29$ to $1.63 ; \mathrm{p}=0.005$ ).

Women of Childbearing Age with a supportive culture were more likely to increase positive attitude $(\mathrm{b}=1.44$; $\mathrm{CI} 95 \%=$ 0.70 to $2.17 ; \mathrm{p}<0.001)$.

\section{DISCUSSION use of long term contraceptive method}

\section{a. Education}

The results of the study showed that the level of education directly influence the use of long term contraceptive method. It suggested that women of childbearing age who had higher education level were more likely to use long term contraceptive method than women of childbearing age who had lower education.

In this study, WCBA with higher level of education could directly influence the use of long term contraceptive method. This study was in accordance with a study conducted by Mota et al. (2015) that women with higher levels of education had the potential to use long term contraceptive method than women with lower levels of education. Education can be a powerful reason for influencing one's behavior. The level of education can affect the mindset of a person to be more mature in determining the pattern of health behavior (Teferra, et al 2015; Sahilemichael, et al, 2015; Tamrie, et al, 2015)

It is concluded that education can have a strong influence on improving the health status of the community. Higher level of education can also help the government in the effort to control the rate of population growth. It may develop better through the mindset of highly educated person than someone with a low education.

\section{b. Attitude}

The results of the study showed that attitude directly influence the use of long term contraceptive method. This suggested that women of childbearing age who had a positive attitude, are more likely to increase the use of long term contraceptive method than women of childbearing age who had negative attitudes.

The positive attitude shown by women of childbearing age has a greater potential to use long term contraceptive method than those who has a negative attitude towards long term contraceptive method. A person who has a negative or positive attitude toward a particular object is influenced by a social concept that is obtained in a mature manner along with the development of the age they have. The development of this social concept is gained through the knowledge and experience of the events generated previously (Gustikawati, 2014). Women of childbearing age who have a positive attitude towards long term contraceptive method are the main targets in promoting the use of long term contraceptive method (Alemayehu, et al, 2012).

Positive attitudes gained through good knowledge of long term contraceptive method is influenced by the right information on the use of long term contraceptive method. Well-developed information will increase good knowledge in the community. A positive attitude toward the use of long term contraceptive method obtained through good knowledge of $\mathrm{L}$ long term contraceptive method will increase the potential use of long term contraceptive method (Tibaijuka et al., 2017; Gebremariam A and Addissie, 2014).

It is concluded that positive attitudes can improve good health behavior as well as efforts to improve knowledge for the community. Increased knowledge coupled 
with the proper dissemination of information on efforts to improve health behavior will influence attitudes to be positive.

\section{c. Decision Making}

The results of the study showed that decision making directly influence the use of long term contraceptive method. This showed that women of childbearing age who made a joint decision making, were more likely to use long term contraceptive method than women of childbearing age who made the decision independently.

Women of childbearing age involving the participation of spouses and health worker in making decisions about the use of family planning are potentially using long term contraceptive method rather than those who do not involve spouses or health worker. A woman of childbearing age who often holds discussions with her spouse/ partner can be interpreted that they have responsibility for their health interests together. The number of discussion frequencies will affect maturity in making choices and increasing the use of long term contraceptive method as the primary choice. (Takele, et al, 2012; Bulto, et al 2014).

One of the decision-making models that can influence the patient in determining her health behavior is shared decision making, that is the health worker supports and gives appropriate information to the patient, so that they are then involved in making decisions about the patient's health behavior. Given the involvement of health workers together with patients, it will greatly increase the use of long term contraceptive method (Manurung, 2013).

It is concluded that communication and frequency between women of childbearing age and their partners will influence the way of decision-making in health behaviors. The presence of support from health worker in obtaining right information for WCBA may also increase the use of long term contraceptive method.

2. Variables that indirectly affect te use of long term contraceptive method

\section{a. The influence of knowledge through attitude}

The results of path analysis showed that knowledge has indirect influence on the use of long term contraceptive method through attitude.

A high level of knowledge will increase the effect on the use of long term contraceptive method (Earsido, et al 2015). This study was in accordance with a study conducted by Anguzu, et al (2015) that knowledge related to previous use of contraceptive tools and the attitudes of women of child-bearing age might influence the use of long term contraceptive method. Attitudes could be influenced by knowledge, experience, and an object embodied in the form of a concrete action. Attitudes influence the emergence of a person's behavior so that one's behavior can be judged from attitudes toward a particular object (Soelaeman, 2008; Hurlock, 2008).

It is concluded that knowledge influences the use of long term contraceptive method through a person's attitude to use long term contraceptive method. Knowledge affects a person's response to a particular object called attitude. Thus a positive attitude is a form of higher knowledge that a person acquires for a particular behavior.

\section{b. The influence of attitude through knowledge}

The results of path analysis showed that attitude has indirect influence on the use of long term contraceptive method through decision making. 
Decision-making which is the result of the actions of a woman of childbearing age to use long term contraceptive method is influenced by their positive attitude in the use of long term contraceptive method. Attitudes become part of decision making because attitudes are a tendency towards responses caused by environmental influences. Attitude is a factor that influences one's behavior and thus to know what action will be done (Hurlock, 2008; Soelaeman, 2008).

It is concluded that a person's attitude is strongly influenced by the response to the environment so that it can potentially take action based on what he/she knows, previous experience, and the results of actions from the surrounding environment. Attitudes can shape the behavior of one's health directly so that it can know the results of actions to be performed.

\section{c. The influence of information access through knowledge}

The results of path analysis showed that information access has indirect influence on the use of long term contraceptive method through knowledge.

The results showed that Women of Childbearing Age who had access to good information about contraceptive tools could increase their knowledge about long term contraceptive method. Increased access to information could be done through health promotion efforts conducted by health workers and media campaigns through health care ads. Efforts to disseminate information on the use of long term contraceptive method may increase the use of long term contraceptive method through perceptual changes that affect knowledge of long term contraceptive method (Credé et al., 2012; Shoupe, 2016). Exposure to information on television and radio can improve something new, recognize the changes that occur in social conditions and also get a better chance and can affect one's perception and behavior about his/her health (Melka, et al, 2015; Law et al. 2016).

It is concluded that the exposure of information through health workers and health services is closely related to the acquisition of knowledge related to family planning and long term contraceptive method. The presence of exposure and access to growing information quickly and widely can increase and accelerate the use of long term contraceptive method in women of childbearing age.

\section{d. The influence of culture through attitude}

The result of this study showed that culture had indirect influence on the use of long term contraceptive method through attitude.

Culture is a knowledge, belief, art, morals, laws, customs and every ability and habit that human beings get as part of a complex and comprehensive society. Cultural values associated with family planning adopted by most women of childbearing age may affect the use of long term contraceptive method family planning (Edberg, 2009; (Gustikawati, 2014); Belda et al., 2017).

It is concluded that the values held in the culture in a person's living environment can influence health behavior. Community culture that supports the use of family planning can affect the attitude of the community to family planning. The values adopted by the community such as the insertion of IUD resulting in bleeding so as to disrupt the worship become an obstacle in the cultural view of the community on the use of family planning. Appropriate dissemination of information on the use of long term contraceptive method needs to be expanded to improve the positive attitude and accuracy of decision making. 


\section{REFERENCE}

Alemayehu M, Belachew T, Tilahun T. (2012). Factors associated with utilization of long acting and permanent contraceptive methods among married women of reproductive age in Mekelle town, Tigray region, north Ethiopia. BMC Pregnancy and Childbirth, 12. https://doi.org/10.1186/1471-2393-12-6

Anguzu R, Tweheyo R, Sekandi JN, Zalwango $\mathrm{V}$, Muhumuza C, Tusiime S, Serwadda D. (2014). Knowledge and attitudes towards use of long acting reversible contraceptives among women of reproductive age in Lubaga division, 1-9.

Badan Kependudukan Dan Keluarga Berencana Nasional (2015). Rencana Strategis Badan Kependudukan dan Keluarga Berencana Nasional Tahun 20152019.

Belda SS, Haile MT, Melku AT, Tololu AK. (2017). Modern contraceptive utilization and associated factors among married pastoralist women in Bale eco-region, Bale Zone, South East Ethiopia. BMC Health Services Research, 17(1), 1-12. https://doi.org/10.1186/s12913-017-2115-5

Bulto GA, Zewdie TA, Beyen TK. (2014). Demand for long acting and permanent contraceptive methods and associated factors among married women of reproductive age group in Debre Markos Town, North West Ethiopia. BMC Women's Health, 14(1). https://doi.org/10.1186/1472-687414-46

Credé S, Hoke T, Constant D, Green MS, Moodley J, Harries J (2012). Factors impacting knowledge and use of long acting and permanent contraceptive methods by postpartum HIV positive and negative women in Cape Town,
South Africa: A cross-sectional study. BMC Public Health, 12(1), 197. https://doi.org/10.1186/1471-2458-12-197

Dinas Kesehatan Kota Madiun. (2015). Profil Kesehatan Kota Madiun Tahun 2014.

Earsido A, Gebeyehu A, Kisi T. (2015). Determinants of Long Acting and Permanent Contraceptive Methods Utilization among Married Women in Hossana Town, Southern Ethiopia: A Case - Control Study. Journal of Pregnancy and Child Health, 2(3). https://doi.org/10.4172/2376127X.1000165

Edberg M (2009). Kesehatan Masyarakat: Teori Sosial dan Perilaku. Jakarta: EGC.

Gebremariam A, Addissie A. (2014). Intention to use long acting and permanent contraceptive methods and factors affecting it among married women in Adigrat town, Tigray, Northern Ethiopia. Reproductive Health, 11(1), 24. http://dx.doi.org/10.1186/1742-4755-11-24.

Gustikawati DAN (2014). Faktor pendukung dan penghambat istri pasangan usia subur dalam penggunaan alat kontrasepsi implant di puskesmas I denpasar utara.

Hurlock E (2008). Psikologi Perkembangan: Suatu Pendekatan Sepanjang Rentang Kehidupan. Jakarta: Erlangga

Kementerian Kesehatan RI. (2014). Situasi dan Analisis Keluarga Berencana. Pusat Data Informasi.

Kementerian Perencanaan Pembangunan Nasional. (2014). Rancangan Awal Rencana Pembangunan Jangka Menengah Nasional 2015-2019. Buku II Agenda Pembangunan Bidang.

Law A, Pilon D, Lynen R, Laliberté F, Gozalo L, Lefebvre P, Duh MS (2016). Retrospective analysis of the impact 
of increasing access to long acting reversible contraceptives in a commercially insured population. Reproductive Health, 13(1). https://doi.org/10.1186/s12978-016-0211-3

Manurung S (2013). Model Pengambilan Keputusan Meningkatkan Akseptor Keluarga Berencana Metode Kontrasepsi Jangka Panjang. Jurnal Kesehatan Masyarakat Nasional, 7(11), $483-488$.

Melka AS, Tekelab T, Wirtu D. (2015). Determinants of long acting and permanent contraceptive methods utilization among married women of reproductive age groups in western Ethiopia: A cross-sectional study. Pan African Medical Journal, 21, 1-10. https://doi.org/10.11604/pamj.2015. 21.246.5835

Mota K, Reddy S, Getachew B (2015). Unmet need of long-acting and permanent family planning methods among women in the reproductive age group in shashemene town, Oromia region, Ethiopia: A cross sectional study. BMC Women's Health, 15(1), 1-8. https://doi.org/10.1186/s12905-0150209-y

Sahilemichael A, Temesgen K, Gemechukejela. (2015). Determinants of Long Acting Reversible Contraceptives Use among Child Bearing Age Women in Dendi District, Western Ethiopia. Journal of Womens Health Care, 4(4). https://doi.org/10.4172/2167-0420.1000242

Shoupe D. (2016). LARC methods: entering a new age of contraception and reproductive health. Contraception and Reproductive Medicine, 1(1): 4. https://doi.org/10.1186/s40834-016-
0011-8

Soelaeman MM (2008). Ilmu Sosial Dasar: Teori \& Konsep Ilmu Sosial. Bandung: Refika Aditama

Takele A, Degu, G, Yitayal M (2012). Demand for long acting and permanent methods of contraceptives and factors for non-use among married women of Goba Town, Bale Zone, South East Ethiopia. Reproductive Health, 9(1): 1-11. https://doi.org/10.1186/1742-4755-9-26

Tamrie YE, Hanna EG, Argaw MD, (2015). Determinants of long acting reversible contraception method use among mothers in extended postpartum period, Durame Town, Southern Ethiopia: a cross sectional community based survey. Health, 7(10), 13151326. https://doi.org/http://dx.doi.org/10.4236/health.2015.710146

Teferra AS, Wondifraw AA (2015). Determinants of Long Acting Contraceptive Use among Reproductive Age Women in Ethiopia: Evidence from EDHS 2011. Science Journal of Public Health, 3(1): 143. https://doi.org/10.11648/j.sjph.20150301.33

Tibaijuka L, Odongo R, Welikhe E, Mukisa W, Kugonza L, Busingye I, Nabukalu P, et al. (2017). Factors influencing use of long-acting versus short-acting contraceptive methods among reproductive-age women in a resourcelimited setting. BMC Women's Health, 17(1): 1-13. https://doi.org/10.1186/s12905-017-0382-2 